\title{
Alay Etmenin Sosyolojik Yönü: Toplumsal Denetim, Damga ve Simgesel Şiddet Bağlamında Alay Etme
}

\author{
The Sociological Aspect of Ridicule: Ridicule within the Context of Social \\ Control, Stigma and Symbolic Violence
}

\section{Gamze KILIÇ * Yelda ÖZEN **}

$\ddot{O}_{z:}$ Toplumsal bir edim olarak alay etme, gündelik hayatın içinde önemli ölçüde varlığını sürdürmektedir. Alay etme ediminin toplumsal etkileşimdeki varlı̆g 1 ve rolü göz önünde bulundurulduğunda, edime toplumsal olarak atfedilen anlamlar önemli hale gelmektedir. Bu çerçevede, bu çalışma, sıklıkla mizahla beraber gündelik hayatın parçası olabilen alay etme ediminin toplumsal yönüne odaklanmaktadır. Makalede, sosyal bilim literatüründe psikoloji ve dilbilim gibi disiplinlerce ağırlıklı olarak ele alınan alay etme edimi, gülme edimi ile ilişkili bir biçimde sosyolojik yaklaşımlar çerçevesinde, sosyolojik kavramlar arasında, özellikle en fazla ilişkili olduğu varsayılan uygarlaşma, toplumsal denetim, benliğin sunumu, performanslar, damga, simgesel şiddet ve benzeri kavramlar açısından tartışılmıştır. Elias, Goffman ve Bourdieu'nün kuramlarının, alay etme ediminin analizi açısından, bize nasıl önemli bir kavramsal zemin oluşturdukları ortaya konmuştur.

Anahtar sözcükler: Alay Etme, Gülme, Mizah, Toplumsal Denetim, Damga, Simgesel Şiddet

\begin{abstract}
Ridicule as a social act continues to exist extensively in everyday life. When considering the existence and the role of ridicule in social interaction, the socially attributed meanings to the act of ridicule become crucial. Within this scope, this study focuses on the social aspect of the act of ridicule, which is predominantly associated with humour as a part of daily life. The act of ridicule as it relates to the act of laughter, dealt with predominantly by disciplines such as psychology and linguistics in social science literature, is explored in this article in terms of civilisation, social control, presentation of the self, performances, stigma, symbolic violence and similar sociological concepts, which are assumed to be the most relevant within the framework of sociological perspectives. Elias, Goffman and Bourdieu's theories are used as an important conceptual basis for the analysis of ridicule.
\end{abstract}

Keywords: Ridicule, Laughter, Humour, Social Control, Stigma, Symbolic Violence

Alay etme, insanlık tarihinde önemli bir gündelik hayat etkileşimi olarak her zaman var olmuştur, ancak eylemin niyetinin ve arkasında yatan toplumsal anlamların genel olarak sosyal bilimlerde özelde ise sosyoloji disiplini içinde yeterince ilgi odağı olmadığ 1 görülmektedir. Toplumsal etkileşimde alay etmeye yüklenen anlamlar kültüre, yer ve mekana göre, kişiler arası ilişki biçimine göre birçok farklı şekillerde yorumlanabilmektedir. Alay etmeyi tek bir tanıma

\footnotetext{
* Yüksek Lisans Mezunu, Ankara Yıldırım Beyazıt Üniversitesi, Sosyal Bilimler Enstitüsü, Sosyoloji, Ankara, gamzekilic@ hotmail.com, https://orcid.org/0000-0002-2125-964X

** Dr. Öğretim Ü., Ankara Yıldırım Beyazıt Üniversitesi, İnsan ve Toplum Bilimleri Fakültesi, Sosyoloji Bölümü Ankara, yeldaozen73@yahoo.com, https://orcid.org/0000-0003-0382-5094
} 
sığdırmak mümkün olmasa da, onun daha çok aşağılayıcı, küçük düşürücü ancak bir o kadar da mizahi bir edim olduğunu söylemek yanlış olmayacaktır. Benzer şekilde alay etmenin çeşitli biçimlerinden söz etmek de mümkündür, gülme, yüz buruşturma, göz devirme gibi mimikler alay etme olarak tanımlanan bedensel davranışlar olarak görülmektedir. Alay etme literatürde sıklıkla gülme ile birlikte ele alınmaktadır. Tarih boyunca, dini otoritelerin yanı sıra, birçok farklı otoritenin gülmeyi denetim alma ve ona yasak koyma girişimlerinin olduğu bilinmektedir (Sanders 2001). Bunun en önemli nedenlerinden birisi gülmenin "alay edici" ve "aşağılayıcı" yönünün, otorite zedeleyici biçimde kullanılabilmesi olmuştur (Sanders 2001). Gülmenin aşağılayıc1 yönüne dikkat çeken üstünlük kuramı (Platon 2007, 2010; Aristoteles 1997, 2013) ise alay etmenin "negatif" yönüne vurguda bulunan bir diğer bakış açısı olarak görülmektedir. Freud'un (1998) mizah üzerine yapmış olduğu çalışmada, bu makalenin hipotezini destekler nitelikte, alay etmenin uygar bir şiddet biçimi olduğu öne sürülmektedir. Ancak modern yaşam biçiminin insan psikolojisi üzerinde yaratmış olduğu stres, kayg1 ve öfkeye karşı, yapılan araştırmalar gülmenin vücut salgılarının etkisi ise insan zihnini "iyileştirici” bir yönü olduğu ortaya konmuştur (Ögüt Eker 2014). İnsanın önemli bir hazzı olarak görebileceğimiz gülmenin, bireyin modern yaşamla mücadelesinde bir psikolojik destek aracı olarak görülmesi, onun alay etme gibi dışlama ve ötekileştirmeyi üreten yönünün arka planda kalmasına neden olmuştur.

Alay etme edimi esasında toplumsal ilişkiler ve etkileşim açısından değerlendirilmesi gereken toplumsal bir olgudur. Alay edilen kişi esasında utanma, mahcup olma gibi duygular yaşamaktadır, kamusal alanda bu tarz duygular ise bireylerin toplumsal statülerini zedeleyebilmektedir. Öte yandan bireyde bırakmış olduğu "iz" düşünüldüğünde alay etmenin sözel bir şiddet biçimi olduğu düşünülebilir. Sosyal ilişki biçimleri üzerinden değerlendirildiğinde alay etmenin, doğrudan ve dolaylı olarak iki farklı biçimde gerçekleştiği görülmektedir (Kılıç 2019). Doğrudan alay etme en az iki kişinin arasında, sözsel biçimde veya bedensel jestlerle gerçekleşmektedir. Gülme ise bu mimikler arasında yer alan en yaygın davranış kalıbı olarak görülebilmektedir. Le Breton Yüz Üzerine Antropolojik Bir Deneme $(2018,224)$ adlı çalışmasında yüz buruşturmanın diğer bir alay etme göstergesi olduğunu ifade etmektedir. Dolaylı alay etmede ise mizah gibi kanallar alay etmenin bir aracı olarak karşımıza çıkmaktadır. Televizyon programları, komedi filmleri, karikatürler gibi güldürü aygıtları işledikleri temalar açısından alay etmeyi merkeze alabilmektedir. Alay etme ile ilişkili, sıkça karşılaşılan temalar arasında etnik köken, toplumsal cinsiyet rolleri, habitus sembolleri ve bedensel görünüm sayılabilir. Dolaylı alay etme yollarından birisi olan mizahta üçüncül kişiler, yani alay etmeye tanık olan ancak alay edilen gruba dâhil olmayan kişiler gülerek tepki verip alay etme edimine dahil olabilmektedir. Alaya maruz kalan kişiler de kimi zaman mizaha gülebilmektedir, bu durum toplumsal kodların içselleştirilmesinin bir örneği olarak görülebilir.

$\mathrm{Bu}$ metin, alay etmenin, sosyoloji disiplininin bize sunduğu kuramsal-kavramsal araçların izini sürerek sosyolojik bağlamda ele almayı ve toplumsal önemine vurgu yapmayı amaçlamaktadır. Alay etmenin sosyolojik yönünün anlaşılabilmesi için, kavramın etrafında yer alan ilgili diğer kavramlarla olan ilişkisinin anlaşılması önemlidir, bu noktada alay etmenin öncelikle gülme ve güldürü unsuru olan mizahla olan ilintisine değinilecektir. Kavramlar arasındaki bu ilişki nedeniyle çalışmada kısa da olsa gülmenin tarihteki yerine, gülmeye ilişkin kuramlara ve alay etmenin gülme ve mizahla olan ilişkisine yer verilmiştir. Ardından, sosyoloji disiplini içinde alay etme edimine kuramsal temel sağladığı düşünülen sosyologlardan Elias'ın alay etmeyi uygar olmayana yönelik bir tepki olarak tanımladığı, uygarlaşma süreci yaklaşımı irdelenecektir. İkinci olarak, gündelik hayat pratiklerinde alay etme ediminin anlaşılmasında Goffman'ın “dramaturji” kuramı karşımıza çıkmaktadır. Bu kurama göre, bireylerin içinde bulundukları alanlara göre niyetlerini ortaya koymak üzere belirli "performansları" sergilemesi gerektiği, performanslar sergilenirken ortaya çıkabilen bozulmalar sonucunda alay etme ve 
damgalamanın bir tepki olarak gerçekleşebileceği belirtilmektedir. Metinde son olarak, Bourdieu'nün simgesel şiddet kavramının alay etme ile olan bağına yer verilmiştir. Yapılan bu tartışmaların temelindeki problem, alay etmenin toplumsal eşitsizliği yeniden üreten bir strateji olduğunun düşünülmesidir. Alay etme, toplumsal-tarihsel ve kültürel bağlama göre değişiklik gösteren toplumsal idealleri ya da normları içselleştiren bireyler tarafından bir hizaya getirme işlevi görmekte ve farklılıkları törpülemeye yönelik bir araç olabilmektedir.

\section{Alay Etmenin Gülme ve Mizahla İlişsisi}

Genel olarak alay etmeye dair literatürün ortaya konabilmesi için, sıklıkla yakın ilişki kurulan gülme ve mizah gibi kavramlara dair çalışmalara yer vermek gerekir. Alay etme ile ilgili doğrudan yoğun kapsamlı bir literatür olduğunu söylemek çok mümkün görünmemektedir, ancak gülme çalışmaları içinde zaman zaman karşılaşabilmekteyiz. Doğrudan alay etmeye dair az sayıda çalışma olması nedeniyle, esas olarak gülme çalışmalarını ele alan ancak alay etmeye de değinen farklı disiplinlerin de içinde olduğu çalışmalara yer verilecektir. Ardından sosyoloji literatürü içinde özellikle de gündelik hayat ve duyguları sosyolojik zemine çeken sosyologların metinlerinde alay etmenin kavramsal düzeyde anlaşılabilmesine zemin oluşturacak kavramsal araçlara yer verilecektir.

Gülme, genelde çeşitli nedenlerden kaynaklanan ve kültürlere göre farklı anlamlar taşıyabilen bir eylem olarak tanımlanmaktadır. Hem fizyolojik hem de duygusal bir eylem olarak görülen gülmeyi tek bir tanıma sığdırmak oldukça zordur. Sıradan bir edim olan gülmenin gündelik dilde kullandığımız anlamı Türk Dil Kurumu'nda (2019) üç farklı tanımla yer almaktadır: "1. Insanın hoşuna veya tuhafina giden olaylar, durumlar karşısında, genellikle sesli bir biçimde duygusunu açığa vurması. 2. Mutlu, sevinçli zaman geçirmek, eğlenmek, hoşça vakit geçirmek. 3. Biriyle alay etmek". Gülme ediminin bu çalışma için önemi ise gülmenin üçüncü tanımında ifade edilen "alay etme" yönüyle, toplumsal ilişkilerde sıklıkla karşılaşıyor olmamızdır. Yine en başta değinilmesi gereken önemli bir nokta mizah, gülme ve alay etme arasındaki üçlü ilişkidir. Mizah ise, fizyolojik olarak gülmeyi açığa çıkaran söze, eyleme veya bir olay örgüsüne dayalı olan güldürü unsuru olarak yorumlanabilmektedir. Mizah kimi zaman alay etmeyi de içeren güldürülere dayanabilmektedir; bu noktada gülünen mizah unsuru alay etmeyi, aşağılama ve küçük düşürmeyi içerebilmektedir.

Gülme, tarihte farklı otoriteler tarafindan sıkl1kla üzerinde düşünülmüş bir eylem olmuştur, bu durumun başlıca nedeni gülmenin bir başkaldırı, otorite zedeleme aracı olarak anlaşılmasıdır (Sanders 2001). Gülmenin olumsuz bir edim olduğu düşüncesi ilk olarak dini öğretilerde karşımıza çıkmaktadır. Semavi dinler ortak olarak gülmenin, alay etme yönüne ve bu alayın bireylerde yaşattı̆̆ tadır (Sanders 2001). Bu yasaklamaları pekiştirmek için gülmeye yönelik olumsuz söylemler ortaya atılmıştır, en sık karşılaşılan örnek ise gülmenin delilikle ilişkilendirilmesi olmuştur. Tarihteki örneklere bakıldığı zaman gülmeye yüklenen bu anlamlarının çoğaltılabileceği görülmektedir. Örneğin Bakhtin'in Rabelais ve Dünyası (2005) kitabında, François Rabelais'in eleştirel, grotesk mizahının kilise ve krallık tarafından aynı nedenle engellendiği anlatılmaktadır. Bunun nedeni gülmenin, "hafif" bir eğlence veya ahlaksız ve "aşağı" kişilerin toplumsal olarak cezalandırılma biçimi olarak görülmesidir (Bakhtin 2005, 95). O dönemde yaygın bir eğlence anlayışı olan karnavallar, otoritelerin baskılarının hafiflediği, halkın "tıpkı şarap fiçılarının çatlamaması için havalarının alınması" şeklindeki eğlencelerdir (Bakhtin 2001, 103). $\mathrm{Bu}$ eğlenceler söz edilen dönemde oldukça yaygındır ve resmi olarak kiliseler tarafından desteklenmese de, dönemin otoritesi olan krallar ve din adamları tarafından gözetim altında gerçekleşebilmektedir. Buradaki amaç yasaklanmış olanı serbest bırakarak halkın rahatlamasını sağlamak, ama aynı zamanda da otoritelerin itibarını korumaktır. 
Gülme ve alay etme ilişkisini anlayabilmek için gülmeye dair ortaya konmuş yaklaşımları bilmek önemlidir. Literatürde yaygın olarak kabul edilen üç temel yaklaşım bulunmaktadır, bunlar: üstünlük, uyumsuzluk ve rahatlama yaklaşımlarıdır.

Bilinen en eski gülme yaklaşımı üstünlük kuramıdır ve tarihi antikçağ filozoflarına dayanmaktadır. Kuramın temel varsayımı, gülmenin bir kişi üzerinde üstünlük kurma amacı gütmesidir. Kuramın gelişmesine ilk katkıyı sunan filozof Platon, gülmeye dair fikirlerinin dikkat çekici bir kısmını Yasalar (2007) kitabında ele almıştır. Gülmenin üstünlük ilişkisi ürettiğini bu nedenle erdemsiz bir davranış olduğunu savunan Platon için insanı gülünç kılan şey kişinin kendini bilmemesinden, yani kişinin kendisini olduğundan daha varlıklı, daha hoş, daha akıllı ve erdemli görmesinden kaynaklanmaktadır (Sanders 2001). Aynı zamanda Platon Devlet (2010, 156-160) kitabında, toplumsal olarak gülünç kabul edilen şeylerden birinin alışılagelmiş olanın, geleneklerin dışında kalan davranışlar olduğunu dile getirmektedir. Bu duruma da yine aynı kitabında, kadınlara jimnastik eğitimi verilmesinin alışılmışın dışında olması nedeniyle gülünç bulunacağına dair yaptığı tartışmada değinmektedir. Platon'un değinmiş olduğu örneklerde gülmenin alay etme niyeti taşıdığı söylenebilir, alay etme özünde aşağılamayı ve bir kimseye karşı üstünlük duygusu taşımayı ifade etmektedir. Bir diğer Antik Çağ filozofu Aristoteles de Nikomakhos'a Etik (1997) adlı eserinde, gülmeye dair detaylı açıklamalarda bulunmuştur. Aristoteles, gülerken kendimizden "aşağı" olan bir şeye ilgi gösterdiğimiz için, aşırı gülmenin erdemli bir yaşamla uyuşamayacağı konusunda israr etmiştir. Aristoteles Poetika $(2013,21)$ isimli çalışmasında dönemin komedyalarının içeriğinden bahsetmiş ve insanların nelere güldükleri konusunda da çıkarımlarda bulunmuştur. Ona göre komedyalarda en sık karşılaşılan güldürü temaları: "çirkinlik", "abartı" ve "kusurdur Nitekim alay etme, bir kişinin kusurlarını ve eksikliklerini hedef almaktadır, bu nedenle gülünen unsurlar gülmenin altında yatan gizil anlamı açığa çıkarmakta önemlidir.

Gülmeye dair geliştirilen uyumsuzluk kuramı, ise bilinen ikinci yaklaşımdır. Bu yaklaşıma göre gülmeye sebep olan şey, algılanan nesne ile bilincimizdeki biçimi arasındaki uyumsuzluktur (Morreall 1997). Biraz daha açacak olursak, bir nesnenin görüntüsünün alışılagelmiş halinin dışında bir biçim almasıdır. Yalnızca nesne değil, bir eylem, bedensel görünüm veya söz dizilimi için de aynısı söylenebilmektedir. Uyumsuzluk kuramının en bilinen iki ismi Kant ve Schopenhauer'dır. Gülmenin nedenini uyumsuzluk olarak açıklayan uyumsuzluk kuramında alay etmeye, alışılmış kültürel kodların dışında olma durumu esnasında karşılaşabiliriz, örneğin toplumsal cinsiyet rollerine dair alışılmış kalıplara uymayan davranışlar uyumsuzluk olarak görülerek alay edilecektir. Ancak üçüncü yaklaşım bize alay etmeye dair çıkarımda bulunabileceğimiz daha fazla açıklama ortaya koymaktadır. Gülmeye dair yaygın olarak bilinen bu üçüncü yaklaşım Freud'un Espriler ve Bilinçdışı ile İlişkiler (1998) isimli kitabında yer verdiği rahatlama kuramıdır. Rahatlama kuramı, üstünlük ve uyumsuzluk yaklaşımlarından farklı olarak gülmeyi fizyolojik bir olgu olarak ele almaktadır. En kısa tanımıyla gülme, gergin olan sinirsel enerjinin serbest bırakılması olarak anlaşılmaktadır. Freud (1998) gülmenin salt psikolojik yönüyle ilgilenmemiş, aynı zamanda onun toplumsal boyutuna da dikkat çekmiştir; gülmeden önce bireylerde biriken gerginliğin sebebini toplumsal baskılara dayandırmaktadır. Şiddet ve cinsellik gibi tabulaştırılmış kavramlara dair şakaların insanları güldürmesinin nedeninin, bu olguların toplumun dini ve ahlaki değerleri tarafından bastırılmasından kaynaklandığını ifade etmektedir. Benzer şekilde Freud (1998), küfür etmenin, küfürlü şakalar yapmanın ve bunlara gülmenin de insanlarda deşarj olma halini karşıladığını ifade etmiştir. Anlaşılacağı üzere Freud $(1998,122)$ gülmeyi esprilere malzeme olan konular üzerinden incelemiştir ve analizleri sonucunda esprinin iki biçimi olduğu kanaatine varmıştır, bunlar "masum espriler" ve "kasıtlı esprilerdir". Ona göre kasıtlı esprinin amacı, hedef alınan kişiye düşmanca bir saldırıda bulunmaktır; dövüşmenin, küfür etmenin ve kötü söz kullanmanın normlar tarafından yasaklandığ 
bir toplumda düşmanlığı ifade etmekte ve rahatlamayı sağlamaktadır. Freud kasıtlı esprilerin toplumda kimi zaman dışlayıcı bir fonksiyonu yerine getirdiğini, kimi zaman ise otorite kuruculara karşı bir direniş işlevi gördüğünü ifade etmiştir. Çalışmasında yer verdiği örneklerde Yahudilikle alay edilen fikralar üzerinde durarak, etnik kökenleri hedef alan şakaların dışlayıcı pratikler olduğunu dile getirmiştir. Freud'ın bakış açısına bir diğer katkıyı da Berger (2014, 146-148) ortaya koymaktadır, bir mizah türü olan hicivi (satire) bir silah olarak tanımlamakta, alay etme şeklinde kişilere hakaret yönelttiğini ifade etmektedir. Taklitçiliğin de aynı şekilde alay edici yönü olduğunu ve bireyi aşağıladığını ifade etmektedir. Bu noktada alay etmenin mizah üzerinden bir dışlama pratiği gerçekleştirdiği konusunda çalışmanın hipotezini destekler açıklamalar ortaya konmaktadır.

Freud'un çağdaşı olan Bergson'ın Gülme (2015) isimli kitabı, alay etme ve gülme ilişkisinin anlaşılması ve toplumsal yönüne vurgu yapması açısından oldukça önemli bir yere sahiptir. Bergson literatürde yer alan gülme kuramlarından etkilenmiş, özellikle üstünlük kuramına dikkat çekmiştir. Bergson'ın gülmeye dair ilk önermesi, gülmenin insana özgü bir eylem olduğuna yöneliktir. $\mathrm{O}$, gülünen şeylerin kendiliğinden değil, insanların ona atfettikleri anlamdan dolayı gülünç bulunabileceğini öne sürmektedir. Herhangi bir insanın yüz ifadesine, bir hayvana veya bir şapkaya gülmemizin nedeninin, onların özünde komik bir görünümleri olması değil; onlara gülünç olduğunu düşündügümüz bir takım anlamlar yüklemiş olmamızdan kaynaklandığını ifade eder (Bergson 2015, 12). Yine Bergson için gülme, toplumsal düzeni sağlayan işlevsel bir cezalandırma biçimi olarak tanımlanmaktadır. Toplumda istenmeyen "ayrıksı" kişiler gülüp, alay edilerek uyarılır ve kişinin yeniden düzene uyması sağlanır. Bu açıdan gülme, Bergson için kolektif bilinci pekiştiren bir eylem olarak görülebilir, çünkü "gülünç bir kusurdur, kişi gülünç olduğunu anlar anlamaz, hiç değilse görünüşte, kendini değiştirmeye çalışacaktır", bu durum da toplumsal düzeni yeniden sağlayacaktır (Bergson 2015, 20).

Alay etme edimine sosyoloji literatüründen çok, psikoloji araştırmalarında (Örn. Mcghee \& Godlstein 1983; Janes 1997; Morreal 1997; Glenn 2003; Lockyer \& Pickering 2005; Ruch 2008) veya dilbilimsel, sanatsal ve tarihsel içerik analizlerinde (Örn. Cameron 1993; Billig 2005; Plaza 2006; Rosenthal et. al. 2016) daha çok gülme olgusu ile beraber ele alınmıştır. Bu araştırmaların bir kısmında alay etme özellikle çocuklar arasında görülen bir zorbalık biçimi olarak tanımlanmakta ve alay etmenin dışlayıcı yönüne dikkat çekilmektedir. Örneğin ırkçılığa dair yapılan çalışmalarda (Mcghee \& Goldstein 2003; Davies 1982) alay etme bir şiddet biçimi olarak tanımlanmaktadır. Güncel literatürde, gülme edimini sosyolojik biçimde ele alan Kuipers ise, Good Humor, Bad Taste (2006) isimli çalışmasında gündelik hayatta karşılaştığımız esprilerin sınıfsal ve etnik boyutlarını incelemiştir. Katılımcılarına, seçilmiş bazı fıkraların komiklik derecelerini sormuş ve Bourdieu'nün sermaye türlerine göre mizah beğenilerini sınıflandırmıştır. Çalışmada, aynı kültür içinde eğitim, yaş, cinsiyet, kır-kent, sosyo-ekonomik düzey gibi değişkenlerin mizah beğenisini, gülmenin anlamlandırılma biçimini etkilediğini ortaya koymuştur. Bireylerin mizah beğenileri onların sosyal sermayelerini ortaya koymaktadır. Kuipers (2006) için bu beğeni farklılıkları toplumda işlevsel bir görev görmektedir, bireyler sınıfsal olarak kendilerini konumlandırmakta ve farklı mizah beğenisi olan kişileri ötekileştirmektedir. Beğeninin yanı sıra, gülmek de alt sınıfa yakıştırılan bayağı bir davranış olarak tanımlanmaktadır, üst sınıf gülme ve kahkaha atmayı uygar bedene yakışmayan "hayvani" bir edim olarak görmektedir (Kuipers 2006, 34). Özellikle etnik şakalar üzerinde duran Kuipers, Hollanda'da bir alt kültürü temsil eden Türklerin, ırkçı şakalara sıklıkla malzeme olduğunu ifade eder. Kuipers'ın çalışması üzerinde durduğu ırkçı fikra ve karikatürlerle mizahın bir “silah" olarak kullanılmasına da örnek sunmaktadır. Kuipers'ın çalışması daha çok gülme ve mizah üzerine olmuş olsa da, kavramsal ve kuramsal çerçevesini Bourdieu'nün kavramsal haritası üzerinden kurması oldukça önemlidir. 
Gülmenin gerçekleşmesine vesile olan mizah ve gülmecenin sosyolojik olarak kendine özgü bir formu olduğu görülmektedir. "Hoş" bir duygu yaratan mizah ve gülmece için sosyolojik açıdan önemli olan mizahın konusudur. Mizah, belirli bir kültürün içinde, kültüre özgü kodlarla şekillenmektedir ve onun bu kültüre özgü oluşu, farklı toplumsal alanlarda farklılaşabildiğinin bir göstergesi olabilmektedir. Bu farklı alanlarda ise gülmecenin içeriği her zaman "hoşa giden" bir duygu yaratma amacında olmamaktadır. İstemli veya istemsiz biçimde mizahta yer verilen temalara bakıldığında belli grupların, davranış örüntülerinin veya bedensel görünümlerin alaycı bir biçimde ele alındığına rastlanmaktadır. Mizahın içinde kendini yeniden üreten bir dışlama ve ötekileştirme mekanizması bulunmaktadır ve her zaman bilinçli bir şekilde yeniden üretilmemektedir. Alay etme edimini gerçekleştiren bireylerin çoğu zaman yaptıkları şaka veya imaların toplumsal anlamı ve etkisinin farkında olduklarını söyleyemeyiz. Dolayısıyla, alay ettiğini söylemek insanların, "ayıp" karşılanacağı gerekçesiyle, rahatlıkla dile getirebileceği ya da itiraf edebileceği bir konu olmaktan uzaktır.

Mizah yoluyla gerçekleştirilen alay etme ve aşağılama, otoriteye karşı bir başkaldırı stratejisi olarak görülmektedir. Türkiye'de önemli bir yeri olan karikatürler, bu başkaldırının birer sembolü olarak karşımıza çıkmaktadır. Cantek'in (2014) ve Cantek ve Gönenç'in (2017) karikatürler üzerinden yapmış olduğu tarihsel çalışmalar, mizahın "direniş" biçimi olarak işlevselliğine örnek olmaktadır. Cantek'e $(2014,22)$ göre "Bugün bir karikatür dergisine gelen yasak ve derginin kapatılması, mizahın gücünün bir göstergesidir". Bu rahatsızlık ve mizaha karş1 verilen sert tepki, alaycı mizahın itibar zedeleyici biçimde algılandığını göstermektedir. Nasreddin Hoca ve Karagöz-Hacivat gibi gelenekselleşmiş mizah tiplemelerinde de s1klıkla alaycılık ve başkaldırı görülmektedir. Nasreddin Hoca, kavuklu ve cübbeli oluşuyla dönemin eğitimli kesimini temsil etmektedir ve siklıkla gelenekle alay etmektedir (Cantek 2014).

Şimşek'in (2014) Yeni Orta Sınıf isimli çalışmasında da karikatürler üzerinden gerçekleşen mizahın damgalama ve ötekileştirme özelliğine değinilmiştir. 1990'lı yıllar için popüler bir mizah aracı olan karikatürlerin içeriğine dikkat çeken Şimşek, kırdan kente göçle beraber yaşanan toplumsal çatışmaların mizaha yansımasına değinmiştir. Alt sınıfı temsil eden bu tiplemelerin en yaygın betimsel özellikleri "arabesk müzik dinleyen, kaba, lahmacun yiyen, yere tüküren, köylü, cinsel yönden fazlasıyla uyarılmış, tacizci” biçimindedir (Şimşek 2014, 82). Bu betimleme, alt sınıfı uygarlaşmamış "hayvani" biçimde tarif etmekte ve bir ötekileştirme üretmektedir.

Bu çalışmalar doğrudan alay etme ile ilgilenmemiştir, ancak alay etmenin toplumsal yönüne dair çıkarımlarda bulunmamız açısından oldukça yararlı olmuşlardır. Mizah ve gülmeyle iç içe geçmiş bir eylem olarak alay etmenin sosyolojik boyutuna dolaylı olarak dahi olsa, bu çalışmalar üzerinden ulaşmak mümkündür.

$\mathrm{Bu}$ makalede yer verilen kuramsal yaklaşımlar birbirinden bağımsız tartışmalar olarak görülebilir, ancak alay etme olgusunun toplumsal boyutu anlaşılmak istendiğinde bu tartışmaların hepsini bir arada düşünmek mümkün görünmektedir. Nitekim alay etme kültürel bir üründür, bu nedenle onu tek bir davranış biçimiyle sınırlamak mümkün görünmemektedir. Toplumsal ilişkilerimizin yalnızca sözlü olarak gerçekleşmediği dikkate alındığında, jestlerimizin ve mimiklerimizin içinde yaşanan kültürel bağlama bağımlı olarak belirli anlamlara büründüğünü görmekteyiz. Bu noktada gülme, alay etmenin yaygın bir biçimi olarak karşımıza çıkmaktadır.

\section{Uygarlaşma, Alay Etme ve Toplumsal Denetim}

Sosyoloji geleneği disiplini içinde alay etme ediminin izini Freud'dan büyük ölçüde etkilenen Norbert Elias'ın sosyolojisinde rastlamaktayız. Duygular ve toplumsal denetim ilişkisine dikkat çeken Elias, Uygarlık Süreci (2013) adlı çalışmasında, incelediği eserlere bakıldığında alay 
etme ilgili dönemin uygarlaşma süreci içinde "medeni olmayana" bir tepki olarak karşımıza çıkmaktadır. Elias'ın düşüncelerinin temelini oluşturan Freud da uygarlaşma konusu ele alınmıştır. Yaşadığımız toplumun kültürel kodlarını erken dönem yaşam deneyimlerimizde edindiğimizi söyleyen Freud, yeni doğmuş insanı, Eros ve Thanatos diye adlandırdığı iki tür içgüdü tarafından yönlendirilen "kaynayan bir kazan" olarak tanımlamaktadır (Shaffer 2008, 39). Eros, bireylerin hayatta kalmalarını sağlayan yaşam içgüdüleridir; soluk alma, üreme, açlık duyma gibi kişileri uyarıcı bir niteliğe sahiptir. Thanatos ise her bireyin kalıtsal olarak sahip olduğu, bireylerin kendilerine ve başkalarına karşı duydukları şiddet dürtüsünü ifade etmektedir (Shaffer 2008). En temelde birey Eros ve Thanatos'unu, yani hayvansal güdülerini dizginleyerek uygar nitelikler taşıma eğilimindedir. Hayvansal güdülerini dizginlemeye çalışan uygar birey id, ego ve süperego arasında bir kimlik çatışması yaşamaktadır. Bireyler doğdukları andan itibaren içinde yer aldıkları kültürle yetişmektedirler ve bu kültür onlara sahip olmaları gereken temel benlik nitelikleri sunmaktadır. Modern dönemde bu kültürel kodların içinde, hemen her kültürde ortak olabilen uygarlık kodları yer almaktadır ve bireye dışsal olarak müdahale edebilmektedir.

Freud (2011) uygarlıktan uzak bir toplumun varlı̆̆ının hayalden öteye geçemeyeceğini ifade etmektedir. Buna karşın, bireyin zorlayıcı ahlak kurallarının aksine hazlarını ve arzularını gerçekleştirmek istemesi, onun farklı yollarla kendini rahatlatma arayışına girmesine neden olmuştur. Freud (1998), bastırılmış olan şiddet duygusuna karşı insanların geliştirdiği savunma stratejilerinden bahsetmektedir, artık yumruk yumruğa dövüşmenin mümkün olmadığı modern dönemde, bireyler birbirlerine karşı duydukları öfke ve düşmanlığı yeni saldırı yollarıyla göstermektedir. Freud'a $(1998,134)$ göre, “düşmanımızı kü̧̈ük, aşă̆l, değersiz ya da gülünç kılarak dolayl bir yoldan onu alt etmenin zevkine ulaşırız". Bu yüzden alay etme medeni bir saldırı biçimi olarak yorumlanabilmektedir. Freud'un (1998) bu savını desteklemek için verdiği örneklerden biri fiziksel bozuklukları olan bireyler ile alay edilmesidir.

Norbert Elias ise, sosyalizasyon süreci ile ilgilenmiş ve uygarlaşma sürecini "sosyal figürasyonlar" kavramıyla açıklamaya çalışmıştır. İnsanın hayvani olarak tanımlanan doğal ihtiyaçlarının ve güdülerinin, yani uygar olmayan yanının, tarihsel süreç içinde ve farklı kültürlerde nasıl değişip bir tabu haline geldiğini ortaya koymaktadır. Elias (2013) için beden "bitmemiş bir projedir" ve o tarihsel süreç içinde farklı anlamlar ve görünümler kazanan bu projenin değişimini "uygarlaşma" kavramı üzerinden açılamaya çalışır.

Elias'a (2013) göre, uygarlaşmaya dair dönüşümler günlük dilde, insanın kendi toplumuna ait insanların eskiye göre "uygarlaştığı" yönündedir, ancak bu dönüşümün altında yatan sosyal gerçeklik yeterince belirgin değildir. Elias bu süreci adab-1 muaşeret kurallarında yaşanan değişim üzerinden ele almaktadır. Örneğin sıklıkla soyluların yemek yeme adabındaki değişimlerinden bahsetmektedir. Etin yenme biçimi, çatal ve kaşığın sofrada kullanılmaya başlanması, yemek yeme hızı, yemek yedikten sonra yemek artıklarının nasıl temizleneceği gibi tarihte daha önce üzerinde durulmamış nezaket kurallarına yapılan vurguya dikkat çekmiştir. Elias kitabında sıklıkla Erasmus'tan alıntı yapmaktadır; Erasmus yaşadığı dönemde adab-1 muaşeret kurallarını anlatmak ve öğretmek için detaylı bir biçimde geğirme, yellenme, tükürme, sümkürme gibi doğal ihtiyaçları karşılama biçimlerini tanımlamaktadır. Elias (2013), bu tanımlamaların detaylı oluşunun modern dönemde dahi rahatsız edici kabul edildiğini, bunun nedeninin ise uygarlaşma düzeyindeki değişim olduğunu dile getirmektedir. Shilling $(2003,136)$ Elias'ın yaklaşımından hareketle, görgü kurallarının altında yatan temel nedenin, insanların hayvanlardan ve doğadan kendilerini kesin şekilde ayırmak istemesi ve uygar insanın artık kendini hayvanlarla ve doğayla tanımlamaktan kaçınması şeklinde ifade etmektedir. Toplumda yaygın olarak karşılaşılan, uygar davranışlar sergilemeyen bireylerle alay etmek de bu bağlamda hayvani yönünü törpüleyememiş bireylere karşı gösterilen bir tepki, uyarı olarak anlaşılabilir. 
Tıp ve sağlık alanındaki gelişmelerle birlikte, görgü kuralları üzerindeki denetim bir bilgi otoritesi altında gerçekleşmeye başlamıştır. Adab-1 muaşeret kurallarının otoritesini güçlendirmek için "hasta olursun" uyarısı sıkça kullanılmış ve insanların uygarlaşma süreci, tıbbi otoritelerin de yardımıyla, korku yoluyla bir miktar hızlandırılmıştır (Elias 2013). Aynı şekilde toplumda istenmeyen ahlaki davranışlara karşı dini otoritenin "günah", "yasak" halk arasında ise "ayıp" gibi söylemlerde bulunulması bir uyarı mekanizması olarak görülebilir.

Elias uygar bedenin başlangıcını herhangi bir tarihe dayandırmamaktadır, fakat Ortaçağ ve Rönesans dönemini kapsayan süreçte gözle görülür değişimler yaşandığını vurgulamaktadır. Elias, toplum yapısındaki bu değişimi toplumun siyasi ve hukuki yapısındaki değişimle ilişkilendirmiştir. The Court Society (1983) isimli kitabında ele aldığ "mahkeme toplumu" kavramsallaştırması Rönesans'ın yeni toplum yapısında mahkemenin toplumsal sorunları çözmedeki önceliğine dikkat çekmektedir. Elias bu kavram ile Rönesans döneminde, otoritesini hukuksal kurallar ile pekiştirmeye çalışan soyluların ve kralların dönemini kastetmektedir. Bu dönemde kaba kuvvetin yanı sıra bürokrasi kendini gösterir ve hukuksal düzenlemeler soyluların çıkarlarını koruyacak şekilde düzenlenir. Dönemin ayırt edici diğer bir özelliği ise halkın şiddete karşı tutumundaki değişimdir. Gündelik hayatın sıradan bir eylemi olarak görülen şiddet, uygar toplum yapısında suç olarak görülmüş ve cezaya tabi tutulmuştur, bu durum bireylerin şiddet konusunda kendilerini dizginlemelerine ve yaşadıkları sorunları şiddet yoluyla değil, mahkeme yoluyla çözmeye sevk etmiştir. Toplumdaki bu bürokratik değişim, uygarlaşma ile paralel bir gelişim seyretmiştir ve tıpkı bireylerin hazlarını denetlemeleri gibi, şiddet dürtülerini denetlemeleri de onların medenileştiklerinin bir kanıtı olarak görülmüştür. Şiddetin bir diğer yönü olan sorun çözme işlevindeki değişimi ise Elias edep kurallarına uymayan bireyler üzerindeki baskıdan ve uyarılardan örneklerle açıklamaktadır. Ona göre, "hataların bu ölçüde nazik, son derece yumuşak ve nispeten saygll bir şekilde düzeltiliş biçimi, bir toplumsal denetim aracı olarak (hele bir de toplumsal hiyerarşinin üstünde yer alanlar tarafindan yapilırsa), son derece zorlayıcl; herhangi bir fiziksel şiddet tehdidinden çok daha etkilidir" (Elias 2013, 171). Bu açılama, fiziksel şiddet yerine insanları utandırmanın günümüz toplumları için çok daha rencide edici olduğunu destekler niteliktedir.

Elias utanma ve mahcubiyeti insanda bulunan bir duygu olarak tanımlamaktadır, bu değerin temelinde de kaygı duygusu yatmaktadır, bu kaygı, diğer bireylerle ilişkiler esnasında yapılacak herhangi bir hatanın kaygısıdır, çünkü mahcubiyet yaşanmasına yol açan sorunlar, başkalarının gözünde itibar yitimine neden olmaktadır. Elias, utandırmanın bu örseleyici ve itibar zedeleyici yönünü modern toplumların denetim ve cezalandırma biçimi olduğuna dikkat çeker. Onun bu yaklaşımı, Goffman'ın "utanma ve mahcubiyete" dair sıkça vurgu yaptığı, "dramuturji" olarak adlandırdığı yaklaşımıyla oldukça ilintilidir. Shilling' in $(2003,141)$ ifadesi ile, Elias'ın bedenin sosyalizasyonu ve rasyonelleşmesine dair yaptığı çalışmayı, Goffman'ın benliğin sunumuna dair geliştirdiği yaklaşımın eksik olan tarihsel arka planını tamamladığını söylemek mümkündür. Elias için gündelik hayat pratiklerinde utanmanın başlıca sebeplerinden biri bireylerin adab-1 muaşeret kurallarına uymamalarıdır. Bu görgü kurallarına uyup uymamak, bireylerin toplumsal konumlarına dair ipuçları da vermektedir. Uygarlaşma daha çok halkın soylu kesimine hitap etmektedir, beden üzerinden gerçekleşen bu incelik kurallarının görünürlüğünün fazla olması da toplumsal tabakalaşmanın sınırlarını belirginleştirmektedir. Adab-1 muaşeret kurallarının yanı sıra tüketim üzerinden de gerçekleştirilen bu dışlama pratiği, Veblen'in Aylak Sinıfin Teorisi (2015) çalışmasında soyluların yaptıkları tüketim üzerinden sınıfsal konumlarını pekiştirdikleri savını hatırlatmaktadır. Veblen bu çalışmada giyim ve yiyecek tüketiminin yanı sıra zaman tüketiminin de sınıfsal konumu belirttiği üzerinde durmuştur. Elias'ın bahsettiği saray soyluları da zamanlarının büyük bir kısmını, kendilerini bedensel olarak daha uygar bir hale dönüştürmek için harcamaktadırlar. 
Elias, modern toplumlarda daha görünür hale gelen bedenlerin tarihsel seyrini çalışmalarında sunmuştur. Kimliğin bedensel görünüm ile bütünleştiği modern toplumlarda, bedenin en ufak bir "hatası" bile bireylerin itibarlarını zedeleyebilmektedir. Bu durum toplumsal ilişki biçimlerini değiştirmiş ve bireyler birbirlerini denetledikleri ve uyardıkları yeni stratejiler geliştirmişlerdir. Elias'ın da ifade ettiği gibi, medenileşmiş mahkeme toplumunun şiddeti bir suç olarak görmesiyle, alay etme, aşağılama ve tiksinme gibi pratiklerle toplumu idealize edilen biçimde yeniden düzenlemektedir. Buna ek olarak, gündelik hayat pratiklerinde uygarlaşmaya dair toplumsal kabulleri yerine getirmeyen bireyler, hızlı bir şekilde fark edilerek alay edilmeye ve ötekileştirilmeye mahkûm edilirler. Yumul (2000) bu ötekileştirmeyi Elias'ın uygarlaşma teorisini benimseyerek ele aldığ 1 makalesinde "siyah ve beyaz Türkler" tanımı üzerinden vermektedir. Kentleşme ile birlikte kırdan kente yaşanan göçler farklı kültürden insanları bir araya getirmiştir. Kırdan gelen bireyler geleneksellik kodlarını taşımaktadır ve Yumul'un tabiri ile siyah Türkleri temsil etmektedirler ve uygarlaşamamayı ellerindeki tesbih, giydikleri kösele ayakkabılar ve düğmeleri yarıya kadar açık gömlekleri temsil etmektedirler. Taşıdıkları bu semboller onların kentli olan beyaz Türkler tarafindan, "zonta", "maganda" ve "kıro" gibi ifadelerle damgalanıp ötekileştirilmesine neden olmaktadır. Bu noktada alay etme uygarlık normlarına uymayan bireylerin utandırılarak cezalandırılmasının bir aracı olarak tanımlanabilmektedir.

Elias'ın çalışması, Goffman'ın yaklaşımını anlamak ve tarihsel bir bütünlük içinde görmek için anlamlıdır. Bu iki yaklaşımın temel noktası, kimlikle bütünleşmiş olan bedenin, gündelik hayat pratikleri ile statü edinmesi veya itibar kaybetmesi üzerine kurulu olan toplumsal ilişki biçimlerini açıklamaktır.

\section{Damgalama ve Dışlama Pratiği Olarak Alay Etme}

Goffman, gündelik hayat ve toplumsal etkileşim çalışmalarının önünün açılmasında etkili bir isim olmuştur. Toplumsal ilişkileri "dramaturji” adını verdiği yaklaşımıyla açıklayan Goffman (2016), kamusal alandaki insan etkileşimini tiyatro oyunu metaforu yoluyla tanımlamaktadır. Bir tiyatro oyununda olduğu gibi bireylerin rolleri önceden belirlenmiştir, oyuncular rollerini en iyi şekilde oynamayı hedeflemektedirler ve bu hedef için uygun kıyafet, dekor ve sahne düzenini edinirler. Beklenen rolü karşılayamamak seyirci tarafindan cezalandırılmakla sonuçlanmaktadır, ceza ise sahneden uzaklaştırılmaktır. Goffman $(2016,31)$, bireylerin toplum içinde sergiledikleri bu performansları sosyalleşme yoluyla öğrendiklerini ifade eder; " $b u$ dünyaya bireyler olarak geliriz, kişilik kazanırız ve birer kişi oluruz" ve bu kişiliği toplumsal beklentileri karşılamak üzere kurarız. Toplumsal beklentilerin karşılanmaması halinde bireyler toplum içinde damgalanmakta ve onlardan yitirilen itibarlarını yeniden kazanmalarını sağlayacak bir çaba beklenmektedir.

Goffman'ın $(2016,28)$ kuramında aktörün eylemlerini ifade eden "performans", "belli bir durumda, belli bir katılımcının, diğer katılımcılardan herhangi birini etkilemeye yönelik tüm etkinlikleri” şeklinde tanımlanmaktadır. Bu tanıma göre kamusal alanda doğrudan veya dolaylı ilişkilerimizde sergilediğimiz davranışların birçoğu performans olarak görülebilmektedir. Performans esnasında sergilenen eylem kalıpları, içinde yaşanılan toplumun beklentilerine göre şekillenmektedir. Goffman (2016) için bireyler, sosyalleşme yoluyla içinde yaşadıkları toplumun idealize ettiği rol beklentilerini öğrenmek zorundadır; tıpkı yabani bir ormanda hayatta kalma mücadelesi veren bir insan gibi, topluma kendini kabul ettirmeye çalışan bireylerin verdikleri mücadele de son derece hayatidir. Sergilenen bu performanslar, bireylerin kamusal alandaki "maskeleridir". Bu maskeler bireyleri "sahne arkasındaki" kişiliğinden çıkarıp, kamusal alana yani "sahne önüne" hazırlamaktadır. Bireyler bu roller aracılığıyla kendi benliklerini sunmakta ve birbirlerini tanımaktadırlar. Goffman'ın performans kavramsallaştır- 
ması, toplumsallaşma sürecinde alay etme edimiyle de ilişkilendirilebilir. Performansın beklentiyi karşılayamaması halinde ortaya çıkan dışlama pratiklerinden birisi alay etmedir. Bireyler alay edildiklerinde kendilerinde bir şeylerin ters gittiğini düşünerek sıklıkla performanslarını yeniden gözden geçirmeye yönelmektedirler.

Performansların beklentiyi karşılayacak biçimde gerçekleşmesi, kişilerin toplum içindeki itibarlarını artırmaktadır ve bu itibar bireylerin sosyal ödülüdür. Goffman (2016), bireylerin itibarlarını korumak ve sahip oldukları itibarı, olduğundan daha iyi gösterebilmek için itibar sembolleri taşıdıklarından bahsetmektedir. Bu semboller sözlü iletişimin olmadığı, ancak beden dili ile iletişimin kurulduğu anlarda kişilerin etkileşim biçimlerini düzenleyen aracılar olarak görülebilmektedir. Beden dili Goffman'ın (2018, 41) tanımıyla "bedensel görünümü, kişisel eylemleri: giyim kuşam, hal hareket ve ses düzeyini selamlaşma biçimi ve bedensel jestler" gibi ifadelerin hepsini kapsamaktadır. Beden dili, katılımcı tarafından, aktörün toplumsal vasıflarını ve benlik algısını, aynı mekânda bulunan diğer bireylere sunacak şekilde düzenlenmektedir. Burada sahip olduğu itibarı beden dili üzerinden sunan bireylerin "gizli tüketim" yollarına başvurduğundan bahseden Goffman $(2016$, 45), bireylerin olumlu bir itibar sergilemek için idealize edilen kültürel pratikleri taklit ettiğini öne sürmektedir. Burada idealize edilen kültür, Elias'ın ve hatta Bourdieu'nün de hemfikir olduğu üst sinıf kültürüdür. Bireyler performanslarını sunmayı öğrenirken, seyircilerin rutinlerine de aşinalık kazanmışlardır. Bu rutinleri, idealize edilen kültürü "beklentisel toplumsallaşma" olarak tanımlayan Goffman $(2016,78)$, beklentiler konusunda eğitilmiş olduğumuzu dile getirmektedir. Toplumsallaşma, bireylerin kamusal alanda uygun bir şekilde davranmaları ve bunun karşılığını alma üzerine kurulmuş bir süreci temsil etmektedir. Bu noktada topluma uygun davranış sergilemiyor olmak dışlama pratiklerini ortaya çıkaracaktır.

Goffman davranış kurallarının bireyi doğrudan ve dolaylı olmak üzere iki biçimde etkilediğini ifade etmektedir. Bunları "asli kurallar" ve "törensel kurallar" olarak iki kategoride ele almaktadır (Goffman 2017a, 41). Bu ayrımın temel sebebi, kuralların ihlalinde gerçekleşen cezalandırma biçimlerinin farklılıklarıdır. Asli kurallar, hukuk, ahlak ve etik kuralları karşılayan, resmi merciler tarafindan denetimi yapılan ve cezalandırma kararına varılan kurallardır. Törensel kurallar ise, töreler, gelenekler gibi resmi olmayan, ancak toplumsallaşma için önemli bir yere sahip olan kurallara karşılık gelmektedir. Törensel kurallar, öncelikle şahsi olarak daha sonra toplumsal olarak denetlenmektedirler. Törensel kurallar nispeten, idealize edilen üst sinıf kültürü ile paralel görülmektedir, bu nedenle kamusal alanda uyulması beklenen törensel kurallar adabı muaşeret kuralları gibi incelikleri içermektedir. Goffman'ın (2018) Toplum Iç̧inde Davranmak çalışmasında verdiği bir örnekte, toplum içinde yemek yeme adabına uymayan otuz yaşına yakın bir erkeğin annesi tarafından psikoloğa götürülmesi anlatılmaktadır. Toplumsal denetim bu örnekte de olduğu gibi yakın çevreden başlayarak odaklanmamış etkileşime dek uzanan geniş bir alanı çevrelemektedir. Beklenen törensel davranışın karşılanmaması durumunda bireyler, toplum tarafindan cezalandırılmaktadır, alay etme de bireyleri utandırarak bu cezalandırmanın bir parçası şeklinde karşımıza çıkmaktadır. Bu durumda alay etme, alay edilen kişiye bir şeylerin yolunda gitmediği, olması gerektiğinden farklı bir biçimde gerçekleştiği duygusunu yaratmaktadır. Goffman'ın (2017b) dışlanma pratiğine karşı, kamusal alanda itibar sahibi olmanın bireyler için önemine dair vurgusu bu noktada yeniden hatırlatılmalıdır. Kamusal alanda bireylerin performansları konusunda özenli olmaları, saygınlık kazanmak veya sahip oldukları itibarı korumak açısından oldukça önemli bir yere sahiptir. İtibar Goffman için, bireylerin ekonomik kazanç elde edebilmelerinden, sosyal etkileşimlerine ve hatta iyi bir eğitim alabilmelerine kadar geniş bir etkisi bulunan, gündelik hayatın şekillenmesinde son derece kritik bir unsurdur. Bireylerin itibarlarının zedelenmesi toplumsal düzenin dışına itilmelerine neden olabilmektedir; bu noktada ise Goffman'ın “damga” kavramı ile karşılaşmaktayız. 
Damga Goffman'a göre, bir ilişki türüdür ve sabit bir nitelikte değildir, zamana ve mekâna göre değişkenlik gösterebilmektedir. Damgalı, "ötekiyle” ilişkilerinde onu itibarsızlaştıran bir vasfa sahip olan kişidir (Goffman 2014, 17). Goffman $(2014,30)$ üç tür damga tanımlamaktadır: bunlar (1) bedensel deformasyonlar; (2) sapkın, katı inançlar veya ahlaksızlık ve (3) etnik, ulus damgasıdır. Damga türleri görünürlüklerine göre toplum içinde farklı şekillerde derecelendirilebilmektedir. Örneğin bedensel engelli bir birey ile eski bir mahkûm aynı damga statüsüne sahip değildir, fakat her durumda damgalı bireyler toplum içinde yer alan "normal" bireyler ile kıyaslandığında "anormal" bireyler olarak görülmektedirler ve çoğu zaman bu durum damgalı bireyler tarafından da içselleştirilmektedir. Goffman'a göre damgasının farkında olan birey, kendini düzeltme ve normalleşme çabası eğilimine girmektedir. Damgalı bireylerin "normal" bir bireye dönüşmesi veya damgasına rağmen normal olana en yakın kimliğe sahip olması, toplum tarafından onaylanmakta ve ödüllere övgülere layık görülmektedir. Goffman'ın (2014) ifadesiyle, kendilerini "normal" olarak kabul ettirebilmiş bütünleşme kahramanlarının başarı öyküleri her yanda anlatılmakta ve diğer damgalıların da aynı mücadeleleri verip "normalleşmeleri" teşvik edilmektedir. Sonuç olarak Goffman, damgalı bireylerin sıradan bir insanın gündelik hayat pratikleri ile aynı ilişki pratiklerine sahip olamadığını söylemektedir. Kamusal alanda damgalarını gizleyebilecekleri stratejiler geliştirerek kendilerine yer edinmeye çalışmaktadırlar. $\mathrm{Bu}$ stratejilerin başlıca nedenleri arasında alay etmekten kaçınmayı görmek mümkündür, çünkü alay etme, bireyleri örseleyici ve aşağılayıcı bir güce sahiptir. Söz konusu eylem onların itibarlarını zedeleyeceği gibi damgalanıp toplumun "normalleri" arasından uzaklaştırılmasına da neden olabilecektir.

Goffman'ın dikkat çektiği bir başka durum ise damganın dinamik bir etkileşim biçimi olmasıdır. Damga, toplumun belli dönemlerinde değişebilen, kendini popüler kültür ile sürekli yenileyen bir kavramdır. Bu durumda bireylerin sürekli olarak bu güncel deneyimleri takip etmeleri beklenmektedir. Bu deneyimlerin içine bedensel görünüm, giyim ve yaşam tarzı, yeme biçimi vs. gibi birçok davranış kalıbı dâhil olabilmektedir. Dinamik olan gündelik hayat akışını takip etmemek de damgalanmanın ve alay edilmenin farklı bir boyutu olarak karşımıza çıkabilmektedir.

Sosyal düzenin içindeki "uyumsuzları" ve "anormalleri" temsil eden akıl hastaları, tarih boyunca damgalanmış bir grup olarak literatüre geçmiştir. Delilik olgusunun anlamı modern tıbbın gelişmesiyle birlikte dönüşüme uğramıştır. Goffman (2018), psikiyatristlerin bir bireydeki psikolojik bozukluğu teşhis ederken ve bu bozukluğun hastanedeki tedavi seyrini takip ederken, genellikle hastanın yürüme, yeme, konuşma gibi gündelik davranışlarının "duruma uygun olmayan" yönlerinden bahsettiklerini ifade etmektedir. Bu tür duruma uymayan yanlış davranışların "akal hastası" olmanın önemli bir işareti olduğunu düşünen psikiyatristlerin sapma niteliğindeki davranışları gözlemlerken bu davranışların çoğunun küçük düşürücü ve utanç verici davranışlar olduğunu ileri sürmüşlerdir. Goffman bu söylemleri dikkate alarak, toplumsal kuralların bireylerin itibarlarını ve toplum içinde aldıkları konumları ne şekilde etkilediğini bir ters okuma ile yeniden çalışmıştır. Toplum İçinde Davranmak (2018) ve Timarhaneler (2015) adlı iki çalışmasında bireylerin neden akıl hastası olarak görüldüklerini, hangi davranışlarının buna sebep olduğunu araştırmıştır. Burada ulaştığ 1 sonuç, bireylerin kamusal alanda törensel kurallara uymadıkları ve toplumsal beklentileri karşılamadıkları takdirde "akıl hastası" olarak anıldıkları şeklindedir. Asli kuralları ihlal eden bireyler, hukuksal olarak cezalandırılan, suçlu olarak tanımlanan bireylerdir; törensel kurallar ise toplum tarafindan denetimi gerçekleştirilen ve ihlal edildiği takdirde toplum tarafından yargılanarak belirli cezalara tabi tutulan kurallardır. $\mathrm{Bu}$ kuralların ihlali ise bireylerin akıl hastası olarak damgalanmalarına değin varmaktadır. Tıpkı Foucault'nun Deliliğin Tarihi (2017) kitabında ortaya koyduğu gibi, toplumsal düzene uymayan bireyler deli, aylak, homoseksüel, yoksul sinıflandırmaları altında cezalandırılmaya tabi 
tutulmaktadır. Delilik imgesi alaycı mizahın da sıklıkla kullandığı bir temadır.

Goffman'ın terminolojisi birbiri ile bağlantılı birçok kavramdan oluşmaktadır, her kavram birbiri ile ilişkili bir bütünlük içinde ele alınmaktadır. Onun kavramlarının her biri, bireyleri gündelik hayat pratiklerinde farkında olarak veya olmayarak geliştirdiği stratejileri tanımlamaktadır. Toplumsallaşma sürecini başarılı bir şekilde tamamlayan bireyler, kamusal alanda idealize edilmiş olan beklentileri eksiksiz şekilde karşılayabilen kişilerdir. Goffman, toplumsallaşma sürecinin detaylarının yanında, toplumsallaşma sürecini başarıyla tamamlayamamış bireylerin toplum içindeki konumlarına da dikkat çekmektedir. Bu şekilde toplumda damgalayan ve damgalananlar olarak iki grubun da bakış açısını çalışmasına yansıtmıştır. Alay etme de Goffman'in bahsettiği damgalama stratejilerinden biri olarak görülebilir.

Goffman, toplumsal düzeni sağlamak ve bireylerin yükümlülüklerini yerine getirdiklerini denetlemek için üç normatif denetim şeklinin varlığından bahseder: Birincisi şahsi denetimdir, kişi kendi kendisinin polisidir. Birey normları ihlal etmemek ve yükümlülüklerini gerektiği şekilde gerçekleştirmek için daima öz-denetim uygular. İkincisi, gayrı resmi toplumsal denetimdir; kişi, ihlale maruz kalan bireyler tarafından kınanıp utandırılarak haddini aştığı yönünde uyarılarak denetlenmektedir. Üçüncü ve son denetleme ise saldırganın toplumsal düzeni bozması durumunda resmi kurumlar tarafindan cezalandırılmasıyla gerçekleşmektedir (Gofmann 2007b, 402). Goffman törensel kurallar tanımlamasında, kural ihlali gerçekleştiren bireylerin toplum tarafindan "kinama ve utandirma" stratejileri ile uyarıldıkların ifade etmektedir. Alay etme toplumsal denetimin bir parçasıdır, bir utandırma pratiğidir ve kişilerin mahcubiyet duymalarını amaçlamaktadır. Mahcubiyet, bir insanın o an orada olduğu hissedilen diğer kişilerin önünde verdiği izlenimle ilgilidir (Goffman 2017a, 113). Alay etme bu noktada beklenen performansın karşılanamaması halinde ortaya çıkan bir dışlama pratiği olarak düşünülebilir; birey utandırılır ve sunduğu performansı tekrarlamaması konusunda uyarılır.

Goffman'ın vitrin kavramı da gerçekleştirilen performanslarla uyumsuzluğu durumunda, alay etme için önemli bir yorum olmaktadır. Kişiler, kamusal alanda sahip oldukları vitrin ve itibar sembolleri ile "odaklanmamış" bir etkileşimin içinde, daha önce tanışmamış oldukları insanlarla beden dilleri yoluyla iletişim kurmaktadır. Bireylerin beden dilleri de bu şekilde toplumsal denetime uğramaktadır. Mahcubiyet duygusu bireyler tarafından yaşanmak istemeyen bir deneyimdir, alay etme ise bireyleri doğrudan utandırmayı hedef almaktadır. Toplumsal denetimde mahcup olacakları bir performans sunmak istemeyen bireyler öncelikle kendi kendilerini denetlemektedirler. Bireyler, üst sınıf kültürü olarak tanımlanan ideal normları öğrenip, bu normlar çerçevesinde stratejiler geliştirmektedir. Goffman (2016), performansını öz denetim içinde gerçekleştiren bireylerin, performansında ideal standartlara uygun bir ifade ortaya koymak için bu standartlarla uyuşmayan eylemlerden vazgeçmek veya onları gizlemek zorunda kalacağını ifade etmektedir. Gizli tüketim bu stratejilere bir örnektir; kişi kendi evinde popüler müzik dinlerken, dışarıda klasik müzik veya caz gibi üst sınıfların tüketim örüntülerinde daha yaygın karşılaşılan müzik türleri tercih edebilmektedir. Aynı şekilde kişi giyimine, saçlarına veya makyajına ev ortamında dikkat etmezken, kamusal alanda statüsünden beklendiği gibi "kaliteli", "markalı" kıyafetler giymek ve şık görünmek için çaba sarf etmektedir. Bu gibi gizli tüketimlerin nedenleri kişilerin alay edilme, dışlanma ve damgalanma korkuları olduğu söylenebilir.

Alay etme ve edilme Goffman'ın kavram setleri ile doğrudan örtüşen kavramlardır. Kamusal alandaki etkileşim kalıpları ile ilgilenen Goffman için alay etme bir damgalama pratiği olarak görülebilmektedir. Alay eden kişi için, alay etmenin sebebi toplumsal düzeni bozan bireyin uyarılarak topluma yeniden kazandırılmasını sağlayabilmek iken; alay edilen için bu durum mahcup olma, utanma ve dişlanma pratiği olarak deneyimlenebilmektedir. 


\section{Simgesel Bir Şiddet Biçimi Olarak Alay Etme}

Alay etme, damgalamanın yanı sıra bireyler üzerinde aşağılanma ve örselenme etkisi yaratabilmektedir. Bu noktada alay etme simgesel bir şiddet biçimi olarak karşımıza çıkmaktadır. Bourdieu simgesel şiddet kavramını yapmış olduğu toplumsal sınıf analizi araştırmaları üzerinden değerlendirmiştir. En bilinen çalışmalarından olan Ayrım (2017) kitabında Bourdieu, bedenin tüketim nesneleri üzerinden yeniden üretilme biçimini ve bu tüketim alışkanlıklarının toplumsal sınıfları inşa etmedeki rolünü ortaya koymuştur. İnşa edilen bu toplumsal sınıf statüleri ise "simgesel şiddet" yoluyla kendini yeniden üretmekte ve sosyal konumunu korumaktadır. Alay etme bu noktada sosyal statünün korunumunu sağlayan ve aynı zamanda yeniden üretiminde rol alan bir simgesel şiddet biçimi olarak değerlendirilebilmektedir.

Bourdieu'nün geliştirmiş olduğu kuramı anlamak, literatüre kazandırmış olduğu zengin kavram setini bilmekle mümkündür. Bourdieu, bireylerin toplum içinde belli eğilimlerle gündelik hayatlarını sürdürdüğünü ifade eder, bu eğilimler habituslardır. Habitus, ne tam olarak bireyseldir ne de davranışların tek başına belirleyicisidir; eyleyicilerin içinde işleyen yaptırımcı bir mekanizmadır (Bourdieu \& Wacquant 2014). Bourdieu (Bourdieu \& Wacquant 2014, 110), habitus kavramını tanımlarken, eylemi eyleyicisiz mekanik bir tepki olarak tanımlamaktan ve eylemi bilinçli bir niyetin kararlı bir şekilde yerine getirilmesi olarak tanımlamaktan kaçınmaktadır. Bourdieu'nün bu ifadesi habitus kavramının yapı-fail ikiliği ile ele alınması gerektiğini ve bu nedenle ilişkisel bir kavram olduğunu ortaya koymaktadır. Bourdieu (Bourdieu \& Wacquant 2014, 116) için habitus, toplumsallaşmış bir öznelliktir. Dış yapıların içselleştirilmesinin ürünü olan habitus, faillerin çeşitli durumlarla başa çıkmalarını sağlayan stratejilerdir. $\mathrm{Bu}$ stratejiler alanın kurallarına göre belirlenmektedir. Bourdieu, alan kavramı ile oyun arasında bir benzerlik kurmuştur; fakat alan, oyundan farklı olarak bilinçli bir yaratımın ürünü değildir, kodlanmamış düzenliliklere uymaktadır. Oyunda, oyuncular arasında bir rekabet söz konusudur ve bu rekabetin belirleyicisi "sermayelerdir". Farklı alanlar farklı sermayeleri gerektirmekte ve oyuncular oyuna farklı sermaye tipleri (ekonomik, kültürel, toplumsal, simgesel) ile yatırım yapabilmektedirler. Alan, oyunun oynandığı toplumsal mekan olarak da düşünülebilir. Eyleyenler, sahip oldukları sermayeler çerçevesinde bir habitus ortaya koyarlar ve alana bu habituslar ile dahil olurlar.

Bourdieu, yaygın olarak bilinen ekonomik sermayenin dışında toplumsal sınıfları düzenleyen üç sermaye biçimi daha tanımlamıştır. Kültürel sermaye, Bourdieu'nün en çok üzerinde durduğu sermaye türlerinden biridir; en temelde bireylerin eğitim yoluyla öğrendikleri bilgileri, davranış kurallarını ve toplumsal normları içermektedir. Sosyal sermaye ise, bireylerin sosyal ilişki ağına, karşılıklı tanış olma sermayesine denk gelmektedir. Simgesel sermayeye ise; her sermayenin içerisinde görülebilecek, sahip olunan simgesel değerler bütünü olarak tanımlanabilmektedir (Özsöz 2007). Simgesel sermaye, diğer sermaye türlerinden bağımsız değildir, alg1 kategorilerine bağlı olarak var olmaktadır. Sermaye, alandaki bireylerin ilişkilerini düzenleyen temel bir mekanizmadır. Farklı sermaye türleri farklı alanların kapısını açmaktadır ve bireylerin toplum içinde sahip oldukları habitus eğilimini belirlemektedir.

Eyleyenlerin sahip oldukları sermayeler, beğenilerini farklılaştırmaktadır; bu noktada beğeni üzerinden gerçekleştirilen tercihler ve tüketimler simgesel değerleri nedeniyle toplum içinde bazen benzerlik sembolü, bazen de damga taşıyıcısı olmaktadır. Estetik konumlamalar sınıfsal konumlamalara işaret etmektedir (Bourdieu 2017, 93). Sermaye ve habitus birbiri ile ilintili kavramlardır, habitus eğilimleri bireylerin beğenilerini belirlemektedir. Bourdieu'nün yaklaşımında bu eğilimlerin ve beğenilerin taşıyıcısı olarak "bedenin" yeri oldukça önemlidir. Onun için herhangi bir seçkinlik arayışının başlangıç noktası, kişinin kendi bedenidir (Iş̧k 1998). Bireylerin besin ve giyim tercihleri, ilgilendikleri spor dalları veya estetik beğeni yargıları sahip 
oldukları sosyal sınıfı simgelemektedir. Bourdieu'nün Ayrım adlı çalışması, Elias'ın Uygarlık Süreci çalışmasıyla ilintili okunabilir. İki çalışmada da toplumsal sınıfların davranış örüntüleri ve beğeni yargıları ile ne şekilde görünürlük kazandığına ve bu görünürlüğün yarattığı sınıfsal ayrıma dikkat çekilmektedir. Shilling'e (2003) göre, Bourdieu, bedensel pratiklerle görünür hale gelen toplumsal sınıfların, dışlanma ve ayrıma ne şekilde maruz kaldıklarını ortaya çıkarmayı amaçlamıştır. Bu durumda alay etme ise, sınıfsal olarak daha keskin bir biçimde görünür olan, dışlanma ve ayrımın bir biçimi olarak okunabilmektedir.

Meşrulaştırılmış toplumsal düzen, Bourdieu'nün yaklaşımında üst sınıf habitusuna karşıllı gelmektedir. Yeniden Üretim (2015) adlı çalışmalarında Bourdieu ve Passeron, eğitim müfredatı üzerinden elde ettikleri bulgularda, eğitim sisteminin üst sınıflar için bir iktidar aracı olduğunu ve sınıfsal yeniden üretimi sağlayarak üst sınıfların konumunu pekiştirdiğini ortaya koymuşlardır. Meşrulaştırılmış toplumsal düzen simgesel şiddet aracılığıyla zor kullanılarak ayakta tutulmaktadır, bu durum ise toplumsal yeniden üretim olarak tanımlanmaktadır (Jourdain \& Naulin 2016). Simgesel şiddet Bourdieu'nün tanımı ile "eyleyici üzerinde kendi suç ortaklığıyla uygulanan şiddet" biçimidir (Bourdieu \& Wacquant 2014, 166). Bourdieu $(2016,11)$ simgesel şiddeti, maruz kalan eyleyiciler tarafından hissedilemeyen, olağan olarak kabul edilmiş, sembolik kanallar yoluyla uygulanan bir şiddet biçimi olarak tanımlamaktadır. Konuşma veya eyleme biçimi, hayat tarzı, bedensel görünüm gibi keyfi sembolleri ideolojik aygıtlar yoluyla bireylere kabul ettirmektedir. Eyleyenler, şiddete maruz kaldıklarının farkında değildirler, onlar için sunulan bu semboller vazgeçilemez ve sorgulanamaz gerçekliklerdir. Simgesel şiddet Freud'un (1998) ifade ettiği "medenileşmiş şiddet” biçimi olarak tanımlanabilir, alay etme de bu şiddet türüne bir örnek oluşturur.

Simgesel şiddet, hâkim sınıf için kültürel bir tahakküm aracı olarak değerlendirilebilir, bu durumda, gelişen teknoloji ile hayatımıza giren yeni medya araçları bu tahakküme aracılık eden, simgesel şiddetin önemli dinamikleri olarak karşımıza çıkacaktır. Hâkim sınıfın kendi lehlerine kamuoyu oluşturmalarında son derece başat olan bu kanallar, hem toplumsal gözetimi hem de yeniden üretimi sağlamaktadır. Kültürel tahakküme karşı korunmanın yolu ise yine aynı kültürün parçası olan "silahları" kuşanmaktan geçmektedir; bunlar "basitleştirilmiş bir dilden kurtulmak, güçlü bir retoriğe sahip olmak, eğitim almak" gibi sermaye unsurlarıdır (Bourdieu 2016, 17). Aynı kaynaklar için mücadele eden sınıflar, alanın gerekliliklerini sağlayamadıkları durumda yeni stratejiler geliştirecektir. Dilsel beceriyi geliştirmek veya iyi bir eğitim alma mücadelesi vermekten daha kolay bir yol olan tüketim stratejileri, alt sinıfin, üst sinıfların tüketim alışkanlıklarını taklit ederek aynı sınıfsal düzlemde olmaya çalışmalarına karşılık gelmektedir. Toplumsal statünün failin bedeninde simgeler aracılığıyla somutlaşması, kişiyi görünür olan eylemlerinde üst sınıfları taklit etmeye sevk etmiştir. Bu strateji ile alt sinıfa mensup bireyler daha prestijli bir statü imajı yansıtacak ve simgesel şiddete maruz kalmaktan kendilerini koruyacaklardır. Simgesel şiddete maruz kalan ve dışlanan bireylerin çözüm yolu ise, kimi zaman farkında olmaksızın otoriteye boyun eğerek, dışlanmalarına sebep olan pratiği idealize edilen eylemle değiştirmekte bulmaktadırlar. Örneğin, idealize edilenden fazla kiloya sahip olan bir birey gündelik hayatında alay edilmeye maruz kalabilmektedir ve bu durumun bir şiddet eylemi olduğunun farkındadır. Bu olayda kişi, problemin alay edenlerde değil kendi kilosunda olduğunu düşünürse, simgesel şiddetin iktidarını kabul etmiş olacaktır. Dalga geçilen kişi kilolarını bir sorun olarak görüp zayıflamaya karar verirse de yeniden üretim sağlanmış olacaktır.

Bourdieu, modern toplumlarda sınıfsal ayrımın, bedenin taşıyıcısı olduğu beğeni ve tüketim pratikleri ile gerçekleştirildiğini ifade etmektedir. Tıpkı Elias'ın yemek yeme ve bedensel temizlik biçimi gibi davranış kalıplarını toplumsal statünün göstergesi olarak analiz etmesi gibi, Bourdieu de beğeniler üzerinden sınıfsal ayrımın ne şekilde gerçekleştiğini ortaya koymuştur. 
Beğenilerin taşıdığı simgesel göstergelerin belirli sınıfları temsil etmeleri, bireylerin toplum içinde sınıfsal konumlarına göre gruplaşmalarını kolaylaştırmıştır. Farklı habitusların bir araya geldiği alanlarda, simgesel şiddet, tarafların kullandığı bir ayrıştırma mekanizmasına dönüşmektedir. Bu yazının odağı olan alay etme, burada simgesel şiddetin bir biçimi olarak düşünülebilir. Alay edilen kişinin eylemleri konusunda kendini değiştirmeye yönelmesi ise sınıfsal tahakkümün kabulüne ve idealize edilen kültürün yeniden üretimine firsat tanımaktadır.

\section{Sonuç yerine}

Toplumsal ilişkiler, gündelik hayatımızın içinde sıradanlaşmış belli kalıplaşmış yargılarla varlığını sürdürmektedir. Bu yargıların birer "kalıp" olarak sürdürülmesi, ifadelerin bir refleks halini almasına ve onlar hakkında daha az sorgulama yapılmasına neden olmaktadır. Bu kalıplaşmış davranış ve iletişim biçimlerinden birisi de çalışmanın konusu olan alay etmedir. Goffman'ın (2016, 2017a, 2017b, 2018) gündelik hayattaki toplumsal etkileşim biçimleri üzerine yapmış olduğu çalışmalar, sıradanlaşmış davranış örüntülerinin altında yatan derin anlamların önemini bize hatırlatmaktadır. Bu bağlamda, alay etmenin bu denli sıradanlaşmış bir olgu olması, onun değersizliğini göstermemekte, aksine, sıradanlaşmış bu eylemin altında yatan anlamların oldukça karmaşık bir yapıda olduğunu düşündürmektedir. Bu çalışma, alay etme ediminin toplumsal yönünü ortaya çıkarabileceğimiz bir kavramsal şema ortaya koyacağ1 düşünülen sosyolojik çalışmaların kavram seti ile alay etmenin toplumsal yönünü anlamaya çalışmıştır. Toplumsal denetim, damga ve simgesel şiddet kavramları ile ilintili görülebilecek olan bu kavramın toplumsal eşitsizliği yeniden üretmedeki rolü tartışılmıştır.

Çalışmada sıklıkla dile getirilen, alay etmenin yakın ilişki içinde olduğu ve literatürde sıklıkla beraber anıldığı bir diğer eylem ise gülmedir. Bergson'a (2015) göre gülme, en az iki insanın bir aradalığı ile mümkün olmaktadır. Gülmeye dair yapmış olduğu bu tanım, edimin etkileşimlerdeki yerine ve sosyolojik önemine dikkat çekmektedir. Gülmenin etkileşimlerdeki bir diğer önemi ise edimin gerçekleşebilmesi için gülünecek bir nedene ihtiyaç duyulmasında karşımıza çıkmaktadır. Bir toplumda gülünç kabul edilen nedir veya kimdir? Öncelikle gülüncün kültür, sosyo-kültürel düzey, yaş, cinsiyet, meslek vs. değişkenlerine bağlı olarak kişiden kişiye değiştiğini söylemek gerekmektedir. Gülünç yalnızca bireyin sahip olduğu kültürel kodlara seslenmesi ile gülünç olma sıfatına erişmektedir. Aynı toplum içinde değişkenlik gösterebilen mizah beğenisinin en keskin hissedildiği değişken Kuipers'ın (2006) da çalışmasında tanımladığı gibi toplumsal sınıflardır. Tıpkı Elias'ın (2013) çalışmasında saray soylularının dışında kalan halkın, özellikle de köylünün uygarlık dışı olduğunu, "domuz" ile özdeşleştirilerek uygar olmayanın hayvani ve doğal alana ait olduğunu gösteren analizlerinde olduğu gibi, alt sınıflara yapıştırılan "medeni olmama" damgası sıklıkla karşılaşılan bir güldürü unsuru olarak günümüzde de karşımıza çıkmaktadır (Dipnot: Elias'ın Uygarlık Süreci kitabında çokça geçmektedir. Örneğin sofra adabı üzerine incelediği şiirlerden biri örnek verilebilir: "Tasa yumulan, görgüsüzce ă̆zını şapırdatan, domuz gibi sesler çıkaran, diğer hayvanların yanına layıktır" (Elias 2013, 175). Toplumun alt kesimleri ile dalga geçmek ve gülmek tarihin birçok döneminde karşılaşılan bir temadır, toplumsal dışlamanın göstergesi olan bu durum bireylerin kendi sosyal konumlarını belirlemelerinin de bir yoludur. Bu noktada Bourdieu'nün tanımladığı kültürel sermayeden bahsedilebilir; zira sosyal sınıfların konumlandırılmasında görünür bir etkiye sahip olan kültürel sermaye, bireylerin gündelik etkileşimlerde ötekileştirilmelerine neden olan, sınıfsal konumlarına dair birçok gösterge ortaya koymaktadır. Yalnızca sosyo-ekonomik durum değil, bireylerin "eksiklik" veya "kusur" olarak atfedilebilecek her niteliği bir güldürü konusu olabilmektedir. Goffman, gündelik hayatın içinde eksiklik ve kusur olarak tanımlanan bu örüntüleri tartışmaya açmıştır ve "sahne önü" olarak tanımlayacağımız kamusal alan "performanslarını" bu kavramlar ile açıklamıştır. Toplumsal etkileşimde herhangi bir eksik veya kusurlu 
davranışta bulunmak, gülünüp alay edilmeye ve damgalanmaya neden olmaktadır. Söz konusu durum, gündelik hayatın sürekli bir öz farkındalık içinde yaşanmasına, "performansların" sosyal normlara uygunluğunun sik sik kontrol edilmesine neden olmaktadır. Alay edilmek ve damgalanmak toplumsal itibarı büyük oranda zayıflatmakta ve bireylerin toplumsal konumlarını tehlikeye sokmaktadır.

İstemli veya istemsiz olarak, damgalama ve hizaya getirme rolünü gerçekleştiren alay etme, Freud'un (1998) ifadesi ile medeni bir şiddet biçimidir. Hayvani yönlerinden sıyrılmaya çalışan medeni beden fiziksel şiddetten uzaklaşarak kendine yeni saldırı yolları aramaktadır. Özellikle mizahın içinde yer edinerek gündelik pratikte bir dışlama mekanizmasına dönüşmektedir. En geniş tabiri ile toplumda alay edilen kişiler "farklı", "alışılmışın dışında" görünen, davranan kişiler olmaktadır. Bu farklılıklar düzen arayışı içindeki toplumsal sistemin içinde kolaylıkla dikkat çekmekte ve "normal" bireyler tarafından müdahale etme isteği uyandırmaktadır. Bu müdahalenin en yaygın yollarından birinin alay etme olduğu söylenebilir. Alay etmenin buradaki amacı hatalı davranışı veya görünümü düzeltmektir. Durkheim $(2014,30)$ da Freud'a benzer şekilde, alaycı gülmenin, örfi kuralları esasa alan toplumsal bir cezalandırma biçimi olduğunu dile getirir. Bu anlamda alay etme Durkheim için, gerçek bir cezalandırma biçimiyle aynı etkiyi yaratmaktadır. Durkheim'ın ortaya koymuş olduğu sosyolojik yaklaşım düşünüldüğünde, alay etmenin onun için toplumsal düzenin tesis edilmesinde yaşanabilecek olası aykırılıkları caydırıcı bir işleve sahip olduğu söylenebilir.

Bir toplumsal denetleme mekanizması olarak görülebilecek olan edim, Elias'ın uygarlaşma süreci ile de oldukça yakın bir ilişki içindedir. Modern insan için normallik tanımı "medenilik" kavramı ile iç içe geçmiş durumdadır, bu nedenle toplumda normal olmayan, alışılmışın dışında olan bireyler uygarlaşma sürecini de yeterince tamamlayamamış olan bireylerden oluşmaktadır. Alay etme, uygarlaşma süreçlerini idealize edilen kalıplarla gerçekleştirememiş olan bireylerin uyarılması ve hatalarının düzeltilerek topluma yeniden kazandırılması için aracı bir edim olarak görülebilir. Bu bağlamda alay etme aynı zamanda Bourdieu'nün ifadesi ile bir "simgesel şiddettir" de. Alay etmenin örseleyici, küçük düşürücü yönü çoğu zaman fiziksel şiddetten daha güçlü bir yara bırakmasına neden olabilmektedir. Aynı zamanda, Bourdieu'nün simgesel şiddetin her zaman bir farkındalık içinde gerçekleşmediğini ifade etmesi, alay etmenin gündelik hayattaki sıradan ve gerçekteki örseleyici anlamından uzak bir biçimde kullanımını açıklamaktadır. Alay etmenin ve alaycı mizahla güldürünün içeriği bu sorunla beraber yeniden düşünülmelidir, medya ağlarının gelişmesi ile beraber mizahın hayatımızın her anına eşlik etmesi, damgalamanın her an gerçekleşebildiğini göstermektedir.

Alay etme, iletişimi başlatan kişinin toplumsal istenirliği gözeterek karşısındaki bireye mesaj ilettiği bir iletişim biçimi olarak da tanımlanabilir. Mesaj iletme biçimi sözlü iletişim kanalları olabileceği gibi, sözsüz iletişimle, örneğin gülme, alaycı gülme ya da mimiklerle yapılan ifadeler gibi beden dili yoluyla da olabilmektedir. Mesajın alıcıya ulaşabilmesi için öncelikle bireylerin aynı toplumsal kodları taşıyor olmaları gerekmektedir. Bunun önemi, alayın ulaştı̆g kişinin alay etmenin toplumsal olarak anlamlandırma ve eyleme biçimini biliyor olup, alayı algılayabilmesidir. Toplumsal bir denetleme işlevi gören alay etme, idealize edilmiş toplumsal normlar üzerinden kendini üretmektedir ve karşıdaki kişinin bir "yanlış" yaptığını dile getirmeyi niyet etmektedir. Bu haliyle şöyle bir tablodan bahsetmemiz mümkündür; alay edenin sözlü veya sözsüz mesajları alayın hedefi olan kişinin davranışlarını değiştirmeyi amaçlayan bir mesajdır. Bergson'ın (2015) ifadesi ile bu durum bir "hizaya getirmeye" karşlık gelmektedir ve toplumsal düzeni sağlamayı amaçlamaktadır.

Alay etme, toplumsal eşitsizliğin üretilmesinde gizli bir yeniden üretim stratejisi olarak görülebilir. Bu çalışmada ortaya konmaya çalışılan temel sorun, alay etmenin gündelik pratiklerde gizil işlevini yürütme biçimi ve alay edilmeye kişilerin belirlenme süreçlerinin izini 
sürmektir. Çalışmada alay edilen bireylerin farklı bedenlere sahip olmak, toplumsal davranış kurallarına uymamak (adab-1 muaşeret gibi) ve idealize edilen habitusun gerekliliklerine sahip olmamak (yoksulluk örneği) gibi ortak yönleri olduğu düşünülmektedir. Alay etme edimi söz konusu olduğunda birbirleri ile iç içe geçmiş olarak karşımıza çıkan "toplumsal denetim", "damga", "performans" ve "simgesel şiddet" kavramları, sıradan bir eylem olarak alay etmenin toplumsal yönünün anlaşılması ve toplumsal eşitsizliğin yeniden üretilmesinin gizil bir stratejisi olarak anlaşılması açısından oldukça önemlidir. Uygarlaşma ile bazı toplumsal normlar bireylere dışsallaşmıştır, bununla beraber kamusal alanda itibar sahibi olmak isteyen bireyler bu normlara uygun performansları gerçekleştirerek statülerini korumayı sürdürmekte ve damgalanmaktan kaçınmaktadırlar. Aynı zamanda bir simgesel şiddet biçimi olarak algılanabilecek olan alay etme, beklentiyi karş1layamayan bireylere karşı gösterilen bir örseleme, küçük düşürme yolu olarak anlaşılmaktadır. Bütün bunlar doğrudan bireylerle yüz yüzeyken yaşanabileceği gibi, belirli toplumsal kimliklerin temsilleri üzerinden mizah ve gülmece yoluyla da gerçekleşebilmektedir. Her zaman özenli bir farkındalıkla gerçekleştirilmeyen alay etme, mizah gibi kanallarla kendini "masumlaştırıp" ırkçılığa varabilecek boyutta eşitsizliklerin yeniden üretilmesini etkilemektedir.

\section{Yazarın Notu}

$\mathrm{Bu}$ çalışma, birinci yazarın, ikinci yazar danışmanlığında 2019 yılında tamamlamış olduğu "Alay Etmenin Farklı Toplumsal Bağlamlardaki Değişen Anlamları Üzerine Fenomenolojik Bir Çalışma" başlıklı yüksek lisans tezinden türetilmiştir.

\section{KAYNAKÇA}

Aristoteles (1997). Nikomakhos'a Etik. Çev. S. Babür. Ankara 1997.

Aristoteles (2013). Poetika: Şiir Sanatı Üstüne. Çev. S. Rifat. İstanbul 2013.

Bakhtin M. (2001). Karnavaldan Romana. Çev. C. Soydemir. İstanbul 2001.

Bakhtin M. (2005). Rabelais ve Dünyası. Çev. Ç. Öztek. İstanbul 2005.

Berger P. L. (2014). Reedeming Laughter. Berlin 2014

Bergson H. (2015). Gülme. Çev. Y. Avunç. İstanbul 2015.

Billig M. (2005). Laughter and Ridicule. London 2005.

Bourdieu P. (2016). Eril Tahakküm. Çev: B. Yılmaz. İstanbul 2016.

Bourdieu P. (2017). Ayrım. Çev. D. F. Şannan \& A. G. Berkkurt. Ankara 2017.

Bourdieu P. \& Passeron, J. C. (2015). Yeniden Üretim. Çev. A. Sümer, Ö. Akkaya \& L. Ünsaldı. Ankara 2015.

Bourdieu P. \& Wacquant L. (2014). Düşünümsel bir Antropoloji için Cevaplar. Çev. N. Ökten. İstanbul 2014.

Cameron K. (1993). Humour and History. London 1993.

Cantek L. (2014). Şehre Göçen Eşek. İstanbul 2014.

Cantek L. \& Gönenç L. (2017). Muhalefet Defteri: Türkiye'de Mizah Dergileri ve Karikatür. İstanbul 2017.

Davies C. (1982). "Ethnic Jokes, Moral Values and Social Boundaries". British Journal of Sociology 33/3 (1982) 383-403.

Durkheim E. (2014). Toplumsal İşbölümü. Çev. Ö. Özankaya. İstanbul 2014.

Elias N. (1983). The Court Society. New York 1983.

Elias N. (2013). Uygarlık Süreci (Cilt 1). Çev. E. Ateşman. İstanbul 2003.

Foucault M. (2017). Deliliğin Tarihi. Çev. M. A. Kılıçbay. Ankara 2017.

Freud S. (1998). Espriler ve Bilinçdışı ile İlişkileri. Çev. E. Kapkın. İstanbul 1998.

Freud S. (2011). Uygarlı̆̆ın Huzursuzluğu. Çev. H. Barışcan. İstanbul 2011.

Glenn P. (2003). Laughter in Interaction. Cambridge 2003.

Goffman E. (2014). Damga: Örselenmiş Kimliğin İdare Edilişi Üzerine Notlar. Çev. L. Ünsaldı, Ş. Geniş \& S. N. Ağırnasli. Ankara 2014.

Goffman E. (2015). Tımarhaneler: Akıl Hastalarının ve Kapatılmıs Diğer Kişilerin Toplumsal Durumu Üzerine Denemeler. Çev. E. Arıcan. Ankara 2015. 
Goffman E. (2016). Günlük Yaşamda Benliğin Sunumu. Çev. B. Cezar. İstanbul 2016.

Goffman E. (2017a). Etkileşim Ritüelleri: Yüz Yüze Davranış Üzerine Denemeler. Çev. A. Bölükbaşı. Ankara 2017.

Goffman E. (2017b). Kamusal Alanda İlişskiler: Toplu Yaşamın Mikro Incelemeleri. Çev. M. F. Karakaya. Ankara 2017.

Goffman E. (2018). Toplum İ̧̧inde Davranmak: Etkileşimlerin Sosyal Düzenine Dair Açıklamalar. Ankara 2018.

Işık E. (1998). Beden ve Toplum Kuramı. İstanbul 1998.

Janes L. M. (1997). The Behavioural Effects of Ridicule of Others. Yayımlanmamış Yüksek Lisans Tezi. University of Western Ontario, Ontario 1997.

Jourdain A. \& Naulin S. (2016). Pierre Bourdieu'nün Kuramı ve Sosyolojik Kullanımları. Çev. Ö. Elitez. İstanbul 2016.

Kılıç G. (2019). Alay Etmenin Farkl Toplumsal Bağlamlardaki Değişen Anlamları Üzerine Fenomenolojik Bir Çalışma. Yayımlanmamış Yüksek Lisans Tezi. Ankara Yıldırım Beyazıt Üniversitesi, Ankara 2019.

Kuipers G. (2006). Good Humor, Bad Taste. Berlin 2016.

Le Breton D. ( 2018) Yüz Üzerine Antropolojik Bir Deneme. Çev. O. Türkay. İstanbul 2018.

Lockyer S. \& Pickering, M. (2005). Beyond A Joke. London 2005.

Mcghee P. E. \& Goldstein, J. H. (1983). Handbook of Humour Resarch. New York 1983.

Morreall J. (1997). Gülmeyi Ciddiye Almak. Çev. K. Aysevener. İstanbul 1997.

Öğüt Eker G. (2014). İnsan Kültü Mizah Eğlence Endüstrisinde Tüketim Nesnesi Olarak Mizah. Ankara 2014.

Özsöz C. (2007). "Pierre Bourdieu'nün Temel Kavramlarına Giriş". Sosyoloji Notlarl 1 (2007) 15- 21.

Platon (2007). Yasalar. Çev. C. Şentunaa \& S. Babür. İstanbul 2007.

Platon (2010). Devlet. Çev. S. Eyüboğlu \& M. A. Cingöz. İstanbul 2010.

Plaza M. (2006). The Function of Humour in Roman Verse Satire. New York 2006.

Rosenthal A., Bindman D. \& Randolph A. (2016). No Laughing Matter. Lebanon 2016.

Ruch W. (2008). "Psychology of Humor". Ed. Victor Raskin. The Primer of Humor Research. Berlin (2008) 17-100..

Sanders B. (2001). Kahkahanın Zaferi. Çev. K. Atakay. İstanbul 2001.

Shaffer D. R. (2008). Social and Personality Development. Belmont 2008.

Shilling C. (2003). The Body and Social Theory. London 2003.

Şimşek A. (2014). Yeni Orta Sinıf- 'Sinik Stratejiler'. İstanbul 2014.

Türk Dil Kurumu. (2019, 12 Mayıs). Gülmek. Erişim adresi: http://sozluk.gov.tr/ .

Veblen T. B. (2015). Aylak Sinıfin Teorisi. Çev. E. Kırmızıaltın, H. Bilir. Ankara 2015.

Yumul A. (2000). "Bitmemiş Bir Proje Olarak Beden”. Toplum ve Bilim 84 (2000) 37-49. 